great experience, objection may $\mathrm{b} \geqslant$ taken. There surely was no necessity for the introduction of such statements as that the value of a mineral in one State might be dependent on a single chemical fact or deposit in a remote State; that a New Jersey iron-founder may have to mix ore from Virginia with ore from Michigan, and procure his fuel from Pennsylvania and his firebrick from Connecticut; and that gold-seekers in Georgia would lack a personal knowledge of California. Does Mr. King suppose that the mining industry of his country will stand still until it is instructed by the Geological Survey? The mining owners and speculators are quite alive to everything likely to be for their interest, and may be safely trusted to look after themselves. "The ironcorps of Wisconsin," he says, "could never safely judge of a Pennsylvania ore, which was required to be mixed with the Wisconsin product, unless the two were investigated together and their direct relations studied." But the Wisconsin corps could perfectly decide as to the amount of metal in the ore and the extent and workability of the deposit. The geological relations are unquestionably most interesting and important, but ignorance of them is bappily not fatal to a very thriving industry.

The Director, it seems to us, does himself and his associates injustice in taking far too low a stand on which to urge the importance of a truly national Survey. In dealing with a popular assembly it is of course necessary to show that a service for which large grants are demanded has a real practical utility. But it is possible to carry this principle too far, and thereby to defeat its object. An acute Congressman might rise and object to such large appropriations being granted for what appeared to be mainly a work of statistics. "Mr. King's letter," he might argue, "puts great stress on the collection of accurate statistics of our mineral wealth. But we don't need a corps of trained geologists with good salaries to scour the country, finding out how many tons of coal are raised here and how many ounces of gold have been crushed there. I can undertake to do all this at a fiftieth part of the cost. All $I$ ask is a couple of clerks and a free postage allowance. I would send a printed form to every mine-owner and district agent in the country, with columns in which to enter all the industrial particulars needed. And I would guarantee to lay before Congress as full and accurate a statement of our mineral output as Mr. King could do with his corps of geologists. Of course if Mr. King is going to make a scientific survey that is another matter. Let him set his corps to work on it, getting the most highly trained men he can find for the purpose. But it would be a waste of brain-power as well as of public money to employ scientific men to do mere clerks' work. Let us have under the Department of the Interior an office for mineral statistics, and leave the Geological Survey free to do proper geological investigation."

There is another part of Mr. King's letter which to an impartial spectator of the discussion cannot but appear ominous of possible evil. He states that it will be among the duties of his Survey "to actually and directly aid in the development of the mineral industry, and promote the wise and guarded influx of foreign capital." Our irrepressible Congressman would no doubt exhaust his eloquence on this topic. "What!" he might exclaim, "are the geologists of the Survey not only to collect statistics, but to be a kind of superior share-brokers and mining speculators? I wonder how much time they are likely to find for really geological work. I hope that they are men far above the love of filthy lucre, anxious only for their country's good, incapable of taking a fee, utterly unbribable. Certainly their virtue will be put to the proof. A mining company stamped with the approval of the Geological Survey will no doubt be more easily floated into the market. On the other hand, a company whose claim is condemned as worthless by the official authorities need not expect its shares to rise in value. Such approval or condemnation will no doubt be naturally regarded by mining men as a purchasable commodity. Even should every member of the Survey keep himself wholly apart from transactions of this kind, it is a misfortune that he should ever be exposed to temptation and to the suspicion which the public knowledge of that temptation so often and so unjustly arouses." No one who knows anything of Mr. King and his associates will for a moment entertain such suspicions, but may resent the mere mention of them. Nevertheless the Survey would do wisely to avoid having anything to do with capital either foreign or domestic. It cannot too jealously guard its scientific reputation. So long as its labours are strictly geological it will be regarded with respect as an impartial tribunal. The moment it begins to meddle with the monetary aspects of mining it will occupy a lower place in public estimation. What is more, it will make enemies. Disappointed speculators will find ample opportunity of revenge; and Mr. King may have a yearly struggle to get his appropriation.

With the most cordial interest in the welfare of the newly-organised Survey and every desire to see it enter upon a long, brilliant, and useful career, we would earnestly urge upon the autborities the desirability, nay, even the necessity, of concentrating as large a part of the force as possible upon the unsurveyed and only partially explored western regions. While this great work is in progress Mr. King will doubtless find ample opportunity of keeping before Congress and the public the industrial aspects of the Survey, and of showing that, even in a pecuniary point of view, the annual expenditure of money is well bestowed. He may be able to make use of the active geological talent of the Eastern States to aid him in collating geological sections and in working out special problems of general interest and importance. In the midst of these labours we do most sincerely trust he will see his way towards collecting material for a first general geological map of the United States. Nothing worthy of the name yet exists, and though many years must elapse before a detailed and accurate map can be issued, a very great boon would meanwhile be conferred, not only on geologists, but on the general public, by the preparation of a map (such as that published by the Lands Office) giving in condensed form the general results of geological investigation all over the Republic.

ARCH. GEIKIE

\section{STONE ARROW HEADS}

M ANY surmises have been offered as to how our prehistoric ancestors could have manufactured stone arrow heads before the uses of bronze or iron were known. Sir John Lubbock, Mr. John Evans, and other writers have suggested that the observations of travellers as to the mode pursued by savage nations in similar work might possibly lead to some correct conclusions. Acting on this hint Mr. B. B. Redding had published an account of the manufacture as practised by the Cloud River Indians. Prior to the close of the Modoc war the Wintoons or Cloud River Indians were without firearms. Up to that time the few settlers who resided about the base of Mount Shasta made it a rule to permit no Wintoon to carry a gun. As there are no agricultural lands and no mines on the Cloud River the Wintoons were left in almost undisputed possession of their prolific huntinggrounds and to the inexhaustible supplies of salmon and trout with which that river abounds. They had but little contact with the Americans until a station was established on their river by the United States Government for the taking of salmon eggs for distribution. Even to this day very few of them have guns, and their principal reliance in the chase is upon their primitive but powerful bow and arrows with stone heads. The stone arrow head maker is still a man of great importance in the tribe, and one of 
the best of these undertook to make, in Mr. Redding's presence, a stone arrow head, using only such tools and implements for this purpose as were in use by the Indians before their contact with the white man. Promptly at the time appointed the old man, Consolulu, appeared, greyhaired, and though between sixty-eight and seventy-two he was still erect and vigorous. He brought, tied upon a deer's skin, a piece of obsidian weighing about a pound, a fragment of a deer's horn, split from a prong lengthwise, about four inches in length and half an inch in diameter and ground off squarely at the ends; this left each end a semicircle, besides two deer prongs with the points ground down into the shape of a square sharp pointed file, one of these being much smaller than the other. $\mathrm{He}$ had also with him some pieces of iron wire tied to wooden handles and ground into the same shapes. These, he said, he used nowadays in preference to the deer prongs, simply because they did not require such constant sharpening. Holding the piece of obsidian in the hollow of his left hand, he placed between the first and second fingers of the same hand the split piece of deer's horn first described, the straight edge of the split horn resting against one-fourth of an inch of the edge of the obsidian, this being about the thickness of the flake he desired to split off, then with a small round water-worn stone which he had picked up, and which weighed perhaps a pound, he with his right hand struck the other end of the split deer's horn a sharp blow. The first attempt resuited in failure; a flake was split off, but it was at the same time shattered to fragments. The next blow was successful, a perfect flake was obtained, and a third was equaliy so. Now squatting on the ground, sitting on his left foot, his right leg extended in tailor-like fashion, he placed in the palm of his left hand a piece of thick, well tanned buckskin ; it was thick but soft and pliable; on this he laid the obsidian flake, holding it firmly in its place by the first three fingers of the same hand; the elbow was steadied on the left knee. In his right hand he took the larger of the two deer prongs and commenced to reduce one edge of the circular form of the flake to a straight line with the thumb of the right hand resting on the edge of the left hand as a fulcrum. The point of the deer prong would be made to rest on about an eighth of an inch or less of the cdge of the flake, then with a firm pressure of the point a conchoidal fragment would be broken out, almost always of the size desired. This operation was repeated until in a few moments the flake was reduced to a straight line on one edge; by rubbing this on the side of the deer horn the sharp edge was worn down. Next, the flake was turned end for end and the chipping renewed; when completed care was taken that the cutting edge was left in the centre. It was now plain that the straight edge thus made was to be one side of the long isosceles triangle, the form of the arrowheads which is used by the tribe. The other side was formed in the same manner and next the base. The chipping but of the slot by which the arrow head is firmly bound by deer tendon to the shaft was the simplest and most rapid portion of the work. It had taken forty minutes to split the two flakes from the obsidian mass and to form one of them into the arrow head. The detailed account of this most interesting process will be found, with illustrations, in the November number of the American Naturalist.

\section{REV. ҰAMES CLIFTON WARD, F.G.S.}

$U R$ geological readers will learn with sincere regret that one of the most earnest of the band of "workers" in this country passed away on April 15, aged 37. Early adducing a taste for science, Mr. Ward was sent to the Royal School of Mines in 1861, studying in the Geological Division, and obtaining the Associateship in 1864. In the following year he joined the staff of the Government Geological Survey, and was sent down to the Yorkshire coalfield, in the survey of which he took an active part. Under the superintendence of Prof. Green he contributed to the elucidation of the geology of seven ordnance quarter sheets, including at least twenty-three maps of Yorkshire, on the scale of 6 inches to the mile, to many Horizontal and Vertical Sections explaining the structure of the coalfield, and furnished information included in the Survey Memoirs on the Dewsbury and Huddersfield district, 88, N.E., in $187 x$, the Burnly Coalfields in 1875 , and the "Geology of the Yorkshire Coalfield" in 1878, and was called before the Royal Coal Commission to give to them the results of his labours in that coalfield. In 1869 Mr. Ward was transferred to the Survey of the English Lake District, then commencing under the superintendence of Mr. Aveline, and we henceforth see Mr. Ward in a new light. Hitherto conscientious work and indefatigable industry had alone characterised him; but so soon as he was surrounded by the scenery of the Lakes, and breathed its exhilarating atmosphere, he developed, in addition to these qualities, a rare appreciation of its beauties, alike present in sunshine and in storm, not far removed from that "being one with nature" that is so marked a characteristic of the litfle band of poets which, in the time that has just gone by, have rendered this district, classic ground for the student of English literature. Keenly enjoying the impressions received from moor and mountain, the search after their origin, the elucidation of their past, and the restoration of their physical geology were ever present in his mind, pursued with a zest and an industry that only can be realised by those who have witnessed it. To pick up a line or clear up a doubtful point he would retrace his steps up the roughest and steepest ground, after a long day's tramp, at a speed that proved the curiosity and interest that he felt in its solution, and after the longest and hardest day in the field we have seen him working at his microscope into the small hours of the night, whilst early the next morning he was ever ready for fresh expeditions, in which no fatigue could check his interest and no discomfort try his good nature. The results of his labours in the Lake District are embodied in the "Keswick Quarter-Sheet" of the Geological Survey and the accompanying memoir on "The Geology of the Northern Part of the English Lake District," published in 1876, and in various official maps and sections, as well as in papers in the Foumal of the Geological Society, the Geological Magazine, Popular Science Review, Science Gossip, and NATURE. To more fully understand the history of the volcanic rocks of his favourite Borrowdale, he undertook a journey to Italy to study Vesuvius and other volcanoes in that region. He spared neither time, cost, nor labour in microscopic sections of rocks and their chemical analyses, to aid his results in the field, and though some German petrographers have questioned some of his results worked out in the laboratory, we doubt whether any future observer will be able to suggest any improvement or change in the elaborate network of boundary lines covering the maps of the northern Lake District.

In his papers on the Lake District he pointed out the radiate arrangement of the ice from the higher grounds during the Glacial Epoch, and the fact that though the rock-basins were scooped out by ice, the amount denuded is an exceedingly small proportion of the entire valley, which was the product of a long period of denudation, and that the district afforded no evidence of a universal ice-cap moving across it in one direction. In his petrographical papers he deduces from "the liquid cavities in quartz-bearing rocks" that the granitoid rocks of the Lake District were consolidated at a depth not greater than 30,000 feet. Comparing the modern volcanic rocks of Vesuvius and Naples with the old lavas of the Lake District and North Wales, he refers the latter to the felstone group, and those of Cumberland to a group. midway between the felstone and the basaltic; in both 